\title{
Uji Kinerja Pompa Air Tenaga Surya Untuk Irigasi
}

(Performance Test of Solar Water Pumps for Irrigation)

\author{
Indra Hoetama ${ }^{1}$, Muhammad Yasar ${ }^{1}$, Ramayanty Bulan ${ }^{1 *}$ \\ ${ }^{1}$ Program Studi Teknik Pertanian Fakultas Pertanian, Universitas Syiah Kuala \\ Corresponding author : rama_bulan@unsyiah.ac.id
}

\begin{abstract}
Abstrak. Ketersediaan air menjadi permasalahan yang mendasar pada sektor pertanian. Sebagai salah satu negara berkembang, Indonesia memiliki daya komsumsi air yang cukup besar dalam kehidupan sehari-hari. Namun pada kondisi geografis Indonesia, beberapa daerah merupakan daerah yang berbukit-bukit dan beberapa daerah terpencil yang memiliki curah hujan yang rendah terkadang menjadi kendala untuk memenuhi kebutuhan air bagi masyarakat. Selama ini teknik pengairan dengan menggunakan pompa air, rata-rata menggunakan pompa listrik yang sumber dayanya berasal dari listrik PLN. Oleh karena itu perlu dirancang pompa yang ramah lingkungan berupa pompa tanpa mesin seperti pompa air tenaga surya. Penelitian ini bertujuan untuk mengetahui kinerja pompa air tenaga surya untuk keperluan irigasi. Pengujian pada pompa air tenaga surya dengan menggunakan 3 variasi kedalaman pipa yaitu 0,5 meter, 1 meter, dan 1,5 meter dengan masing-masing sudut panel $0^{\circ}$ dan $10^{\circ}$. Pompa air ini menggunakan panel surya berjenis SPM$100 \mathrm{~W}$ serta baterai aki Panasonic LC-X1275CH sebagai sumber tenaga, dengan sumber air yang berasal dari bak sumber air. Pada penelitian ini pompa air menghasilkan nilai daya listrik yang bersifat dinamis pada saat pengukuran dengan sudut $0^{\circ}$ dan $10^{\circ}$. Pengujian pompa air pada kedalaman pipa 0,5 meter menghasilkan daya listrik pompa air sebesar 132 Watt, pada kedalaman 1 meter menghasilkan daya listrik pompa air sebesar 154 Watt dan pada kedalaman pipa 1,5 meter menghasilkan daya listrik pompa air sebesar 176 Watt. Energi pompa air tertinggi terdapat pada hari Jumat, 7 September 2018 yakni sebesar $64.627,2 \mathrm{~J}$ pada sudut panel surya $10^{\circ}$. Sedangkan energi pompa air terendah didapat pada hari Minggu, 9 September 2018 yakni sebesar $6.996 \mathrm{~J}$ pada sudut panel surya $10^{\circ}$. efisiensi pompa air tertinggi terdapat pada hari Jumat, 7 September 2018 yaitu sebesar $10,872 \%$ pada sudut panel surya $10^{\circ}$. Sedangkan nilai efisiensi pompa air terendah yakni terdapat pada hari Minggu, 9 September 2018 yaitu sebesar 2,958\% pada sudut panel surya $10^{\circ}$. debit air tertinggi terdapat pada hari Sabtu, 8 September 2018 yaitu sebesar $0,000432 \mathrm{~m}^{3} / \mathrm{s}$ pada sudut panel surya $10^{\circ}$. Sedangkan debit air terendah terdapat pada hari Minggu, 9 September 2018 yaitu sebesar $0,000230 \mathrm{~m}^{3} / \mathrm{s}$ pada sudut panel surya $10^{\circ}$.
\end{abstract}

\section{Kata kunci : Pompa Air, Tenaga Surya, Variasi Kedalaman Pipa}

Abstract. The availability of water is a fundamental problem in the agricultural sector. As one of the developing countries, Indonesia has considerable water consumption in daily life. However, in Indonesia's geographical conditions, some regions are hilly areas and some remote areas that have low rainfall are sometimes an obstacle to meeting the water needs of the community. Recently, irrigation techniques using a water pump, use an electric pump whose resources come from the State Electricity Company. Therefore it is necessary to design an eco-friendly water pump in the form of a pump without a machine such as a solar water pump. This research aims to determine the performance of solar water pumps for irrigation purposes. Tests on solar water pump using 3 pipe depth variations, there is 0.5 meters, 1 meter, and 1.5 meters with each panel angle $0^{\circ}$ and $10^{\circ}$. This water pump uses an SPM-100W solar panel and a Panasonic LC-X1275CH battery as a source of energy, with water sources coming from a cistern. In this research the water pump produces a dynamic value of electrical power when measuring at an angle of $0^{\circ}$ and $10^{\circ}$. Testing the water pump at 0.5 meter pipe depth produces electric power of $132 \mathrm{Watt}$, at a depth of 1 meter producing electric power of 154 Watt and at a depth of 1.5 meters the pipe produces electric power of 176 Watt. The highest water pump energy is on Friday, September 7, 2018 which is 64,627.2 J at the angle of the solar panel $10^{\circ}$. While the lowest water pump energy is obtained on Sunday, September 9, 2018 which is 6,996 J at the angle of the solar panel $10^{\circ}$. the highest water pump efficiency is on Friday, September 7, 2018 which is $10.872 \%$ at the angle of the solar panel $10^{\circ}$. While the lowest water pump efficiency value is found on Sunday, September 9, 2018 which is $2.958 \%$ at the angle of the solar panel $10^{\circ}$. the highest water discharge is on Saturday, September 8,2018 which is $0,000432 \mathrm{~m}^{3} / \mathrm{s}$ at the angle of the solar panel $10^{\circ}$. While the lowest water discharge is on Sunday, September 9, 2018 which is $0,000230 \mathrm{~m}^{3} / \mathrm{s}$ at the angle of the solar panel $10^{\circ}$.

Keywords : Pumps, Solar Water, irrigation 


\section{PENDAHULUAN}

Pompa adalah komponen sistem yang paling dipahami oleh para petani, karena di hampir semua kasus, mereka sudah menggunakan pompa-pompa sejenis (Green et al, 2017). Menurut Wardjito (2012), pompa merupakan alat yang digunakan untuk memindahkan fluida dari tekanan yang lebih rendah ke tekanan yang lebih tinggi atau posisi yang lebih rendah ke posisi yang lebih tinggi. Salah satu jenis pompa yang banyak dipakai untuk kebutuhan industri adalah pompa sentrifugal. Setiadi dan Djoni (2013) juga menjelaskan bahwa suatu fluida akan menerima energi mekanis dari pompa sehingga dapat mengalir dari suatu tempat ke tempat tertentu. Prinsip utama pompa yakni membuat perbedaan tekanan antara saluran masuk (suction) dan saluran keluar (discharge). Dengan adanya perbedaan tekanan maka fluida dapat mengalir. Menurut Ariawan (2013), motor arus bolak-balik atau alternative current menggunakan arus listrik yang membalikkan arahnya secara teratur pada rentang waktu tertentu. Motor listrik memiliki dua bagian dasar listrik terdiri dari stator dan rotor. Stator merupakan komponen listrik statis atau diam. Rotor merupakan komponen listrik berputar untuk memutar as motor. Kecepatan motor alternative current lebih sulit dikendalikan dibandingkan dengan motor direct current.

Yasar et al (2017) menyatakan bahwa selama ini untuk mengairi suatu, potensi curah hujan dianggap memenuhi kebutuhan air pada tanaman tertentu. Namun, gejala perubahan iklim global menyebabkan usaha budidaya yang hanya bertumpu pada air hujan tidak dapat diharapkan sepenuhnya. Lebih lanjut Setiadi et al (2017) menjelaskan kebutuhan air irigasi dilahan pertanian terutama pada wilayah persawahan cenderung mengalami peningkatan pada musim kemarau. Hal ini menyebabkan petani menggunakan pompa diesel untuk memenuhi kebutuhan air irigasi. Apribowo et al (2017) juga menjelaskan bahwa pengunaan pompa air berbahan bakar BBM sagatlah mahal, boros, dan tidak efektif, sehingga dibutuhkan alternatif solusi berupa pompa air berbahan bakar energi terbarukan yang nantinya dapat meningkatkan produktivitas hasil pertanian petani. Seiring dengan kemajuan teknologi dan ilmu pengetahuan telah banyak ditemukan sumber energi terbarukan sebagai penganti BBM. Salah satunya adalah pemanfaatan teknologi Pembangkit Listrik Tenaga Surya (PLTS) yang digunakan untuk sumber energi pengerak pada pompa.

Saputra (2015) menjelaskan bahwa, semakin dalamnya sumber air, maka kinerja pompa air akan semakin meningkat dan waktu yang dibutuhkan untuk melakukan pengisian bejana menjadi lebih lama. Selain itu, kinerja panel surya kurang maksimal dapat dikarenakan beban yang lebih besar dibandingkan dengan kapasitas yang dihasilkan oleh panel surya, sehingga panel surya memerlukan baterai atau accu membantu menyuplai daya untuk menghidupkan beban.

\section{METODE PENELITIAN}

\section{Tempat dan Waktu Penelitian}

Penelitian ini dilaksanakan di Kebun Percobaan I Fakultas Pertanian, Fakultas Pertanian Universitas Syiah Kuala Banda Aceh. Waktu penelitian dilaksanakan pada bulan Juni 2018 sampai Januari 2019

\section{Alat dan Bahan}

Alat yang akan digunakan pada penelitian ini yaitu ampere, volt, ohm meter (AVO Meter), clamp meter, obeng, kunci pas nomor 10, stopwatch Bahan yang digunakan dalam penelitian ini antara lain panel surya SPM-100W, pompa air Panasonic GP-129JXK, 
controller, inverter, pipa PVC ukuran 0,75 inci, baterai aki Panasonic LC-X1275CH dan air di dalam bak sumber air.

\section{Metode Penelitian}

Tahapan dalam penelitian ini meliputi perancangan sistem pembangkit listrik tenaga surya, pengujian fungsional, pengujian pompa air dan pengambilan data. Pengujian dilakukan dengan menggunakan 2 sudut panel dengan perlakuan 3 variasi kedalaman pipa.

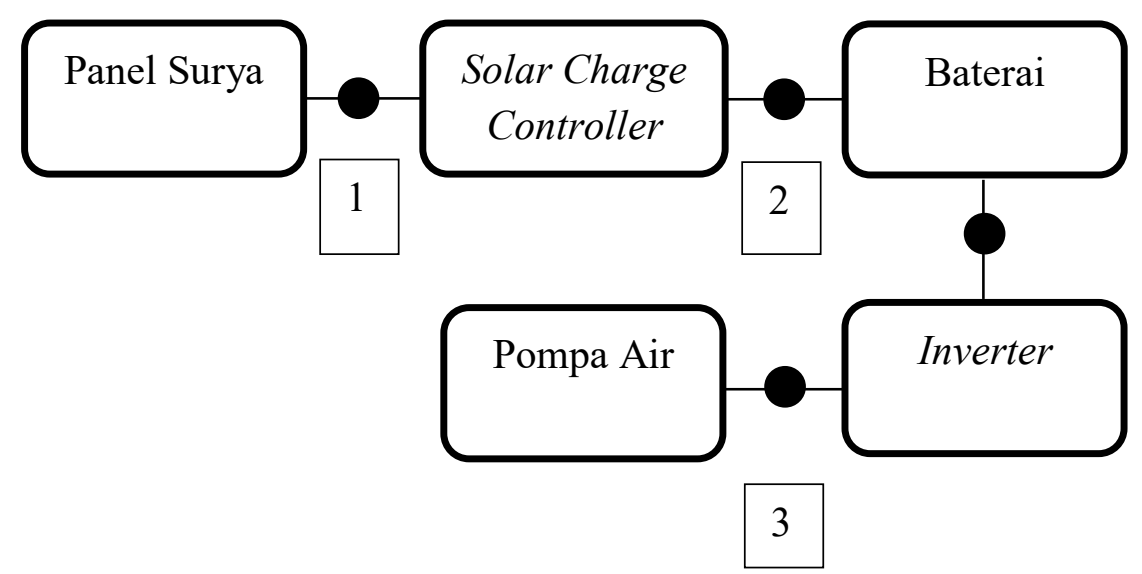

Keterangan :

$1=$ Titik Pengukuran $\mathrm{Q}_{1}$

$2=$ Titik Pengukuran $\mathrm{Q}_{2}$

$3=$ Titik Pengukuran $\mathrm{Q}_{3}$

Gambar 1. Rangkaian Titik Pengukuran

\section{Analisa Teknik}

Daya Listrik

$$
\mathrm{P}=\frac{V^{2}}{R}
$$

Keterangan :

$\mathrm{P} \quad=$ Daya Listrik pada Panel (watt)

$\mathrm{V} \quad=$ Tegangan Listrik pada Panel (volt)

$\mathrm{R} \quad=$ Hambatan Listrik $(\Omega)$

\section{Hambatan Listrik}

$\mathrm{R}=\frac{V}{I}$.

Keterangan :

$\mathrm{R}=$ Hambatan Listrik $(\Omega)$

$\mathrm{V}=$ Tegangan Listrik (volt)

Energi Matahari

$=$ Arus Listrik (A)

$\mathrm{Q}_{\text {matahari }}=\mathrm{I} \times \mathrm{A} \times \mathrm{t}$ 
Keterangan:

$\mathrm{Q}_{\text {matahari }}=$ Energi Matahari $(\mathrm{J})$

I $=$ Iradiasi Surya $\left(\mathrm{W} / \mathrm{m}^{2}\right)$

A $\quad=$ Luas Permukaan Panel Surya $\left(\mathrm{m}^{2}\right)$

$\mathrm{t}=$ Waktu (s)

Energi Listrik ( $Q_{\text {listrik }}$

$\mathrm{Q}_{\text {listrik }}=\mathrm{P} \times \mathrm{t}$

Keterangan:

$\mathrm{Q}_{\text {listrik }}=$ Energi Listrik $(\mathrm{J})$

$\mathrm{P} \quad=$ Daya Listrik $(\mathrm{w})$

Efisiensi

$\mathrm{t} \quad=$ Waktu $(\mathrm{s})$

$\eta=\frac{\text { Qout }}{\text { Qin }} \times 100 \%$

Keterangan :
$\eta \quad=$ Efisiensi $(\%)$
Qout $=$ Energi Output $(\mathrm{J})$
$\mathrm{Q}_{\text {in }} \quad=$ Energi Input $(\mathrm{J})$

Debit Air

$\mathrm{Q}=\frac{V}{t}$

Keterangan :

$\mathrm{Q} \quad=$ Debit Air $\left(\mathrm{m}^{3} / \mathrm{s}\right)$

$\mathrm{V} \quad=$ Volume Penampang $\left(\mathrm{m}^{3}\right)$

$\mathrm{t} \quad=$ Waktu (s)

\section{Tekanan Air}

$\mathrm{P}=\rho \times \mathrm{g} \times \mathrm{h}$

Keterangan :

$\mathrm{P}=$ Tekanan Air $(\mathrm{Pa})$

$\rho=$ Massa Jenis Air $\left(\mathrm{kg} / \mathrm{m}^{3}\right)$

$\mathrm{g}=$ Gravitasi $\left(\mathrm{m} / \mathrm{s}^{2}\right)$

$\mathrm{h}=$ Kedalaman pipa $(\mathrm{m})$

\section{HASIL DAN PEMBAHASAN}

\section{Analisa Teknik}

Analisa teknik tentang perhitungan kinerja pompa air tenaga surya meliputi sudut panel surya yaitu sudut $0^{\circ}$ dan sudut $10^{\circ}$ serta beberapa kedalaman pipa input yakni 0,5 meter, 1 meter, dan 1,5 meter. Selanjutnya dilakukan pengukuran tegangan listrik dan arus listrik pada panel surya, baterai aki dan pompa air. Setelah diperoleh nilai pengukuran tegangan listrik dan arus listrik terhadap panel surya, baterai aki dan pompa air selanjutnya dilakukan perhitungan hambatan listrik dan daya listrik terhadap terhadap panel surya, baterai aki serta pompa air. Perhitungan selanjutnya yakni menghitung energi matahari, 
energi listrik pada panel surya, energi listrik pada baterai aki dan energi listrik pada pompa air. Data pada pompa air diperoleh saat pompa air dihidupkan dengan menggunakan energi listrik dari baterai aki. kemudian dilakukan perhitungan debit air, tekanan air, efisiensi panel surya, efisiensi baterai aki, efisiensi pompa air, efisiensi pompa air terhadap panel surya dan efisiensi pompa air terhadap matahari.

\section{Hasil Penelitian}

\section{Pompa Air Tenaga Surya}

Pompa air yang digunakan pada penelitian ini yakni pompa air berjenis motor arus bolak-balik atau alternative current. Keunggulan dari pompa air jenis motor arus bolakbalik adalah biaya operasional pompa air berjenis motor arus bolak-balik lebih rendah dibandingkan pompa air berjenis motor arus searah, biaya perawatan pompa air berjenis arus bolak-balik lebih rendah dibandingkan pompa air berjenis motor arus searah dan lebih andal dibandingkan pompa air berjenis motor arus searah.

Namun dalam pengujiannya, pompa air berjenis motor arus bolak-balik dapat menyala tetapi tidak dapat digunakan apabila waktu sudah sore hari pada kondisi cuaca berawan maupun cuaca cerah. Menurut Ariawan et al (2013), dengan pengujian menggunakan 4 buah panel surya pada pukul 16.00 dalam cuaca berawan pompa air berjenis motor arus bolak-balik tetap menyala namun tidak mampu menaikkan air sama sekali. Sedangkan pada pompa air berjenis motor arus searah, pompa air menyala dan mampu menaikkan air hingga ketinggian 1 meter. Dalam kondisi cuaca cerah pada pukul 16.00 pompa air berjenis arus bolak-balik dan pompa air berjenis arus searah tetap menyala namun pompa air berjenis motor arus searah mampu menaikkan air hingga ketinggian 1,5 meter. Sedangkan pompa air berjenis motor arus bolak-balik tidak dapat menaikkan air sama sekali. Pengujian pompa air tenaga surya ini sangat dipengaruhi oleh faktor lokasi, sehingga kedalaman pipa yang diuji tidak sistematis karena keadaan sumber air yang tidak dapat diatur.

Tabel 1 dan Tabel 2 menunjukkan nilai kedalaman pipa input $(\mathrm{h})$, nilai pengukuran iradiasi surya (I), tegangan listrik (V), arus listrik (I) dan nilai perhitungan hambatan listrik (R). Nilai tegangan listrik panel surya tertinggi terdapat pada sudut $0^{\circ}$ yakni pada hari Senin, 3 September 2018 sebesar 16,59 Volt dan tegangan listrik terendah terdapat pada sudut $0^{\circ}$ yakni pada hari Rabu, 5 September 2018 sebesar 13,67 Volt. Nilai arus listrik panel surya tertinggi terdapat pada sudut $10^{\circ}$ pada hari Jumat, 7 September 2018 sebesar 13,8 Ampere dan nilai arus listrik panel surya terendah terdapat pada sudut $10^{\circ}$ sebesar 5,4 Ampere. Nilai hambatan listrik tertinggi pada panel surya terdapat pada sudut $10^{\circ}$ yakni pada hari Minggu, 9 September 2018 sebesar 2,559 $\Omega$ dan nilai hambatan listrik terendah terdapat pada sudut $10^{\circ}$ pada Jumat, 7 September 2018 sebesar $1,16 \Omega$. Nilai hambatan listrik pada panel surya ini dihitung untuk mengetahui besar arus listrik yang mengalir dari panel surya.

Baterai aki menghasilkan nilai tegangan listrik tertinggi pada sudut $0^{\circ}$ pada hari Senin, 3 September 2018 sebesar 13,19 Volt dan nilai tegangan listrik terendah terdapat pada sudut $10^{\circ}$ pada hari Sabtu, 8 September 2018 sebesar 12,5 Volt. Nilai arus tertinggi pada baterai aki terdapat pada sudut $10^{\circ}$ pada hari Jumat, 7 September 2018 sebesar 12,9 Ampere dan nilai arus listrik terendah pada baterai aki terdapat pada sudut $10^{\circ}$ pada hari Minggu, 9 September 2018 sebesar 5,1 Ampere. Nilai hambatan listrik pada baterai aki tertinggi terdapat pada sudut $0^{\circ}$ yakni pada hari Minggu, 9 September 2018 sebesar 2,52 $\Omega$ dan nilai hambatan listrik terendah terdapat pada sudut $180^{\circ}$ pada hari Jumat, 7 September 2018 sebesar $0,99 \Omega$. 
Pompa air menghasilkan nilai tegangan yang bersifat konstan sebesar 220 Volt pada saat pengukuran dengan sudut $0^{\circ}$ dan $10^{\circ}$. Pengujian pompa air kedalaman pipa 0,5 meter menghasilkan arus listrik sebesar 0,6 Ampere, pada kedalaman pipa 1 meter menghasilkan arus sebesar 0,7 Ampere dan pada kedalaman pipa 1,5 meter menghasilkan arus sebesar 0,8 Ampere. Berdasarkan hasil perhitungan daya listrik pada tabel diatas dapat diartikan bahwa semkain besar kedalaman pipa, maka arus yang dibutuhkan pompa air juga semakin besar. Nilai tertinggi hambatan listrik pada pompa air terdapat pada hari Kamis, 6 September dan hari Minggu, 9 September 2018 dengan kedalaman pipa 0,5 meter dan diperoleh hasil perhitungan sebesar $366,667 \Omega$ sedangkan nilai terendah terdapat pada hari Rabu, 5 September dan hari Minggu, 7 September 2018 dengan kedalaman pipa sebesar 1,5 meter dengan hasil perhitungan sebesar $275 \Omega$.

Perbedaan nilai tegangan listrik dan arus listrik pada penelitian ini disebabkan karena terjadi fluktuasi nilai iradiasi surya yang didapat oleh panel surya sehingga pada saat panel surya menerima iradiasi yang tinggi maka panel surya juga akan menghasilkan tegangan listrik dan arus listrik yang tinggi. Perbedaan hasil perhitungan hambatan listrik dipengaruhi oleh besarnya nilai arus listrik, semakin besar nilai arus listrik maka nilai hambatan listrik semakin kecil. Besarnya nilai arus listrik dipengaruhi oleh keadaan cuaca pada saat pengujian. Pada nilai hambatan listrik terendah untuk panel surya, baterai aki dan pompa air, keadaan cuaca pada saat pengujian cenderung sangat cerah dan matahari tidak terhalang oleh awan, sehingga nilai arus listrik yang didapat juga besar.

Tabel 1. Tegangan Listrik, Arus Listrik dan Hambatan Listrik Untuk Panel Surya, Baterai Aki, dan Pompa Air pada Sudut Panel $0^{\circ}$

\begin{tabular}{lcccccccccccc}
\hline \multirow{2}{*}{$\begin{array}{l}\text { Hari/Tanggal/Waktu } \\
\text { Percobaan }\end{array}$} & $\mathrm{h}$ & $\mathrm{I}$ & \multicolumn{3}{c}{ Panel Surya } & \multicolumn{3}{c}{ Baterai Aki } & \multicolumn{3}{c}{ Pompa Air } \\
\cline { 5 - 13 } & $(\mathrm{m})$ & $\left(\mathrm{W} / \mathrm{m}^{2}\right)$ & $\mathrm{V}$ & $\mathrm{I}$ & $\mathrm{R}$ & $\mathrm{V}$ & $\mathrm{I}$ & $\mathrm{R}$ & $\mathrm{V}$ & $\mathrm{I}$ & $\mathrm{R}(\Omega)$ \\
& & & $(\mathrm{V})$ & $(\mathrm{A})$ & $(\Omega)$ & $(\mathrm{V})$ & $(\mathrm{A})$ & $(\Omega)$ & $(\mathrm{V})$ & $(\mathrm{A})$ & 0,7 \\
\hline $\begin{array}{l}\text { Senin, 3 September 2018 } \\
\text { pukul 15.00 WIB }\end{array}$ & 1 & $2.942,84$ & 16,59 & 11,9 & 1,394 & 13,19 & 11,4 & 1,157 & 220 & 0,7 & 314,286 \\
$\begin{array}{l}\text { Rabu, 5 September 2018 } \\
\text { pukul 15.00 WIB }\end{array}$ & 1,5 & $1.697,13$ & 13,67 & 5,6 & 2,441 & 12,86 & 5,4 & 2,381 & 220 & 0,8 & 275 \\
$\begin{array}{l}\text { Kamis, 6 September 2018 } \\
\text { pukul 15.00 WIB }\end{array}$ & 0,5 & $2.485,72$ & 16,29 & 9 & 1,810 & 13,04 & 8,7 & 1,499 & 220 & 0,6 & 366,667 \\
\hline
\end{tabular}

Tabel 2. Tegangan Listrik, Arus Listrik dan Hambatan Listrik Untuk Panel Surya, Baterai Aki, dan Pompa Air pada Sudut Panel $0^{\circ}$

\begin{tabular}{|c|c|c|c|c|c|c|c|c|c|c|c|}
\hline \multirow{2}{*}{$\begin{array}{c}\text { Hari/Tanggal/Waktu } \\
\text { Percobaan }\end{array}$} & \multirow{2}{*}{$\begin{array}{l}\mathrm{h} \\
(\mathrm{m})\end{array}$} & \multirow[b]{2}{*}{$\begin{array}{c}\mathrm{I} \\
\left(\mathrm{W} / \mathrm{m}^{2}\right)\end{array}$} & \multicolumn{3}{|c|}{ Panel Surya } & \multicolumn{3}{|c|}{ Baterai Aki } & \multicolumn{3}{|c|}{ Pompa Air } \\
\hline & & & $\begin{array}{c}\mathrm{V} \\
(\mathrm{V})\end{array}$ & $\begin{array}{c}\text { I } \\
\text { (A) }\end{array}$ & $\begin{array}{c}\mathrm{R} \\
(\Omega)\end{array}$ & $\begin{array}{c}\mathrm{V} \\
(\mathrm{V})\end{array}$ & $\begin{array}{c}\text { I } \\
\text { (A) }\end{array}$ & $\begin{array}{c}\mathrm{R} \\
(\Omega)\end{array}$ & $\begin{array}{c}\mathrm{V} \\
(\mathrm{V})\end{array}$ & $\begin{array}{c}\mathrm{I} \\
\text { (A) }\end{array}$ & $\mathrm{R}(\Omega)$ \\
\hline $\begin{array}{l}\text { Jumat, } 7 \text { September } 2018 \\
\text { pukul } 15.00 \text { WIB }\end{array}$ & 1,5 & 3062,86 & 16,02 & 13,8 & 1,161 & 12,8 & 12,9 & 0,992 & 220 & 0,8 & 314,286 \\
\hline $\begin{array}{l}\text { Sabtu, } 8 \text { September } 2018 \\
\text { pukul } 15.00 \text { WIB }\end{array}$ & 1 & $2.337,13$ & 14,4 & 7,4 & 1,946 & 12,5 & 6,9 & 1,812 & 220 & 0,7 & 275 \\
\hline $\begin{array}{l}\text { Minggu, } 9 \text { September } 2018 \\
\text { pukul } 15.00 \mathrm{WIB}\end{array}$ & 0,5 & $1.759,7$ & 13,82 & 5,4 & 2,559 & 12,88 & 5,1 & 2,525 & 220 & 0,6 & 366,667 \\
\hline
\end{tabular}

Tabel 3 dan Tabel 4 menunjukkan nilai kedalaman pipa input (h), nilai pengukuran iradiasi surya (I), tegangan listrik (V), hambatan listrik (R), dan nilai perhitungan daya listrik (P). Nilai daya listrik pada panel tertinggi terdapat pada hari Jumat, 7 September 2018 yaitu sebesar 221,076 Watt pada sudut panel surya $10^{\circ}$. Sedangkan nilai daya listrik terendah terdapat pada hari Minggu, 9 September 2018 yaitu sebesar 76,628 Watt pada sudut panel surya $10^{\circ}$. Daya listrik yang dihasilkan panel akan digunakan oleh baterai aki 
yang mana kemudian baterai aki akan menghasilkan daya pula sehingga dapat menggerakkan pompa air.

Baterai aki menghasilkan nilai daya listrik tertinggi terdapat pada sudut $10^{\circ}$ yakni pada hari Jumat, 7 September 2018 sebesar 165,120 Watt. Sedangkan nilai daya listrik terendah terdapat pada sudut $10^{\circ}$ pada Minggu, 9 September 2018 sebesar 65,688 Watt. Pengujian pompa air pada kedalaman pipa 0,5 meter menghasilkan daya listrik sebesar 132 Watt, pada kedalaman pipa 1 meter menghasilkan daya listrik sebesar 154 Watt dan pada kedalaman pipa 1,5 meter menghasilkan daya listrik sebesar 176 Watt. Berdasarkan hasil perhitungan Tabel 3 dan Tabel 4 dapat diartikan bahwa semakin besar hambatan listrik, maka daya listrik yang dibutuhkan pompa air akan semakin kecil.

Tabel 3. Daya Listrik Untuk Panel Surya, Baterai Aki, dan Pompa Air pada Sudut Panel $0^{\circ}$

\begin{tabular}{|c|c|c|c|c|c|c|c|c|c|c|c|}
\hline \multirow{2}{*}{$\begin{array}{c}\text { Hari/Tanggal/Waktu } \\
\text { Percobaan }\end{array}$} & \multirow{2}{*}{$\begin{array}{c}\mathrm{h} \\
(\mathrm{m})\end{array}$} & \multirow{2}{*}{$\begin{array}{c}\mathrm{I} \\
\left(\mathrm{W} / \mathrm{m}^{2}\right)\end{array}$} & \multicolumn{3}{|c|}{ Panel Surya } & \multicolumn{3}{|c|}{ Baterai Aki } & \multicolumn{3}{|c|}{ Pompa Air } \\
\hline & & & $\begin{array}{c}\mathrm{V} \\
(\mathrm{V})\end{array}$ & $\begin{array}{c}\mathrm{R} \\
(\Omega)\end{array}$ & $\mathrm{P}(\mathrm{W})$ & $\begin{array}{l}\mathrm{V} \\
(\mathrm{v})\end{array}$ & $\begin{array}{c}\mathrm{R} \\
(\Omega)\end{array}$ & $\mathrm{P}(\mathrm{W})$ & $\begin{array}{l}\mathrm{V} \\
(\mathrm{v})\end{array}$ & $\mathrm{R}(\Omega)$ & $\begin{array}{c}\mathrm{P} \\
(\mathrm{W})\end{array}$ \\
\hline $\begin{array}{l}\text { Senin, } 3 \text { September } 2018 \\
\text { pukul } 15.00 \mathrm{WIB}\end{array}$ & 1 & $2.942,84$ & 16,59 & 1,394 & 197,421 & 13,19 & 1,157 & 150,366 & 220 & 314,286 & 154 \\
\hline $\begin{array}{l}\text { Rabu, } 5 \text { September } 2018 \\
\text { pukul } 15.00 \text { WIB }\end{array}$ & 1,5 & $1.697,13$ & 13,67 & 2,441 & 76,552 & 12,86 & 2,381 & 69,444 & 220 & 275 & 176 \\
\hline $\begin{array}{l}\text { Kamis, } 6 \text { September } \\
2018 \text { pukul } 15.00 \text { WIB }\end{array}$ & 0,5 & $2.485,72$ & 16,29 & 1,810 & 146,610 & 13,04 & 1,499 & 113,448 & 220 & 366,667 & 132 \\
\hline
\end{tabular}

Tabel 4. Daya Listrik Untuk Panel Surya, Baterai Aki, dan Pompa Air pada Sudut Panel $10^{\circ}$

\begin{tabular}{|c|c|c|c|c|c|c|c|c|c|c|c|}
\hline \multirow{2}{*}{$\begin{array}{c}\text { Hari/Tanggal/Waktu } \\
\text { Percobaan }\end{array}$} & \multirow{2}{*}{$\begin{array}{c}\mathrm{h} \\
(\mathrm{m})\end{array}$} & \multirow{2}{*}{$\begin{array}{c}\mathrm{I} \\
\left(\mathrm{W} / \mathrm{m}^{2}\right)\end{array}$} & \multicolumn{3}{|c|}{ Panel Surya } & \multicolumn{3}{|c|}{ Baterai Aki } & \multicolumn{3}{|c|}{ Pompa Air } \\
\hline & & & $\begin{array}{c}\mathrm{V} \\
(\mathrm{V})\end{array}$ & $\begin{array}{c}\mathrm{R} \\
(\Omega)\end{array}$ & $\mathrm{P}(\mathrm{W})$ & $\begin{array}{c}\mathrm{V} \\
(\mathrm{V})\end{array}$ & $\begin{array}{c}\mathrm{R} \\
(\Omega)\end{array}$ & $\mathrm{P}(\mathrm{W})$ & $\begin{array}{l}\mathrm{V} \\
(\mathrm{V})\end{array}$ & $\mathrm{R}(\Omega)$ & $\begin{array}{c}\mathrm{P} \\
(\mathrm{W})\end{array}$ \\
\hline $\begin{array}{l}\text { Jumat, 7 September } 2018 \\
\text { pukul 15.00 WIB }\end{array}$ & 1,5 & 3062,86 & 16,02 & 1,161 & 221,076 & 12,8 & 0,992 & 165,120 & 220 & 314,286 & 176 \\
\hline $\begin{array}{l}\text { Sabtu, 8 September } 2018 \\
\text { pukul 15.00 WIB }\end{array}$ & 1 & $2.337,13$ & 14,4 & 1,946 & 106,560 & 12,5 & 1,812 & 86,250 & 220 & 275 & 154 \\
\hline $\begin{array}{l}\text { Minggu, } 9 \text { September } \\
2018 \text { pukul } 15.00 \mathrm{WIB}\end{array}$ & 0,5 & $1.759,7$ & 13,82 & 2,559 & 74,628 & 12,88 & 2,525 & 65,688 & 220 & 366,667 & 132 \\
\hline
\end{tabular}

Tabel 5 dan Tabel 6 menunjukkan nilai kedalaman pipa input (h), nilai daya listrik pompa air $\left(\mathrm{P}_{\text {pompa }}\right)$, nilai pengukuran lama waktu pompa air beroperasi $(\mathrm{t})$ dan nilai perhitungan energi listrik pompa (Q). Nilai energi listrik pompa air tertinggi terdapat pada hari Jumat, 7 September 2018 yakni sebesar 64.627,2 J pada sudut panel surya $10^{\circ}$. Sedangkan energi pompa air terendah didapat pada hari Minggu, 9 September 2018 yakni sebesar $6.996 \mathrm{~J}$ pada sudut panel surya $10^{\circ}$. Perbedaan nilai energi yang dihasilkan pompa air dikarenakan lamanya waktu pompa air bekerja. Semakin lama waktu pompa air bekerja maka energi listrik yang dihasilkan pompa air semakin besar pula. Pada penelitian ini, waktu pompa air bekerja berpengaruh terhadap besarnya energi listrik yang dihasilkan dari baterai aki. Pompa air dihidupkan dari energi listrik yang disuplai oleh baterai aki. Hal ini menegaskan bahwa semakin besar energi listrik yang disalurkan baterai aki maka semakin lama pompa air akan bekerja.

Tabel 5. Energi Pompa Air pada Sudut Panel $0^{\circ}$

\begin{tabular}{ccccc}
\hline Hari/Tanggal/Waktu Percobaan & $\mathrm{h}(\mathrm{m})$ & $\mathrm{P}_{\text {pompa }}(\mathrm{W})$ & $\mathrm{t}(\mathrm{s})$ & $\mathrm{Q}_{\text {pompa }}(\mathrm{J})$ \\
\hline Senin, 3 September 2018 pukul 15.00 WIB & 1 & 154 & 247,2 & $38.068,8$ \\
Rabu, 5 September 2018 pukul 15.00 WIB & 1,5 & 176 & 63 & 11.088
\end{tabular}


Tabel 6. Energi Pompa Air pada Sudut Panel $10^{\circ}$

\begin{tabular}{lcccc}
\hline \multicolumn{1}{c}{ Hari/Tanggal/Waktu Percobaan } & $\mathrm{h}(\mathrm{m})$ & $\mathrm{P}_{\text {pompa }}(\mathrm{W})$ & $\mathrm{t}(\mathrm{s})$ & $\mathrm{Q}_{\text {pompa }}(\mathrm{J})$ \\
\hline Jumat, 7 September 2018 pukul 15.00 WIB & 1,5 & 176 & 367,2 & $64.627,2$ \\
Sabtu, 8 September 2018 pukul 15.00 WIB & 1 & 154 & 124,2 & $19.126,8$ \\
Minggu, 9 September 2018 pukul 15.00 WIB & 0,5 & 132 & 53 & 6.996 \\
\hline
\end{tabular}

Tabel 7 dan Tabel 8 menunjukkan nilai kedalaman pipa input (h), nilai energi listrik pompa air ( $\left.Q_{\text {pompa }}\right)$, nilai energi listrik baterai aki ( $\left.Q_{\text {baterai }}\right)$, dan nilai perhitungan efisiensi pompa air $\left(\mathrm{n}_{2}\right)$. Nilai efisiensi pompa air tertinggi terdapat pada hari Jumat, 7 September 2018 yaitu sebesar $10,872 \%$ pada sudut panel surya $10^{\circ}$. Sedangkan nilai efisiensi pompa air terendah yakni terdapat pada hari Minggu, 9 September 2018 yaitu sebesar 2,958\% pada sudut panel surya $10^{\circ}$. Perbedaan nilai efisiensi pompa air disebabkan karena besar energi listrik yang disuplai oleh baterai aki ke pompa air berbeda. Semakin besar energi listrik yang terdapat pada baterai aki maka pompa air akan menerima energi yang besar pula sehingga nilai efisiensi yang dihasilkan semakin besar.

Tabel 7. Efisiensi Pompa Air pada Sudut Panel $0^{\circ}$

\begin{tabular}{|c|c|c|c|c|}
\hline Hari/Tanggal/Waktu Percobaan & $\mathrm{h}(\mathrm{m})$ & $\mathrm{Q}_{\text {pompa }}(\mathrm{J})$ & $Q_{\text {baterai }}(\mathrm{J})$ & $\eta_{\text {pompa }}(\%)$ \\
\hline Senin, 3 September 2018 pukul $15.00 \mathrm{WIB}$ & 1 & $38.068,8$ & $541.317,6$ & 7,033 \\
\hline Rabu, 5 September 2018 pukul 15.00 WIB & 1,5 & 11.088 & $249.998,4$ & 4,435 \\
\hline Kamis, 6 September 2018 pukul 15.00 WIB & 0,5 & 26.136 & $408.412,8$ & 6,399 \\
\hline
\end{tabular}

Tabel 8. Efisiensi Pompa Air pada Sudut Panel $10^{\circ}$

\begin{tabular}{lcccc}
\hline \multicolumn{1}{c}{ Hari/Tanggal/Waktu Percobaan } & $\mathrm{h}(\mathrm{m})$ & $\mathrm{Q}_{\text {pompa }}(\mathrm{J})$ & $\mathrm{Q}_{\text {baterai }}(\mathrm{J})$ & npompa $(\%)$ \\
\hline Jumat, 7 September 2018 pukul 15.00 WIB & 1,5 & $64.627,2$ & 594.432 & 10,872 \\
Sabtu, 8 September 2018 pukul 15.00 WIB & 1 & $19.126,8$ & 310.500 & 6,160 \\
Minggu, 9 September 2018 pukul 15.00 WIB & 0,5 & 6.996 & $236.476,8$ & 2,958 \\
\hline
\end{tabular}

Tabel 9 dan Tabel 10 menunjukkan nilai kedalaman pipa input (h), nilai iradiasi surya (I), nilai lama waktu pompa air beroperasi (t), nilai volume air pada hasil output (V) dan nilai perhitungan debit air (Q). Dapat dilihat bahwa nilai debit air tertinggi terdapat pada hari Sabtu, 8 September 2018 yaitu sebesar $0,000432 \mathrm{~m}^{3} / \mathrm{s}$ pada sudut panel surya $10^{\circ}$. Sedangkan debit air terendah terdapat pada hari Minggu, 9 September 2018 yaitu sebesar $0,000230 \mathrm{~m}^{3} / \mathrm{s}$ pada sudut panel surya $10^{\circ}$. Debit air merupakan banyaknya volume air yang dapat ditampung pada suatu medium per satuan waktu sehingga semakin besar perbandingan antara volume air dengan waktu pompa air bekerja maka semakin besar debit air yang dikeluarkan.

Irigasi merupakan pemanfaatan air di bidang pertanian. Irigasi berfungsi untuk mengalirkan ke lahan yang ditanami tumbuhan terutama tumbuhan yang membutuhkan banyak air. Pada penelitian ini belum diaplikasikan sistem irigasi terhadap tanaman menggunakan pompa air tenaga surya. Namun, dapat diterapkan penggunaan sistem irigasi 
sederhana. Pada penelitian ini, didapatkan nilai debit tertinggi sebesar $0,000432 \mathrm{~m}^{3} / \mathrm{s}$ dengan menggunakan 1 panel surya, hal ini dapat dikatakan bahwa penelitian ini lebih baik karena menghasilkan nilai debit sebesar $0,000432 \mathrm{~m}^{3} / \mathrm{s}$ dengan menggunakan 1 panel surya. Sedangkan pada penelitian yang dilakukan oleh Setiadi et al (2017) menghasilkan debit air sebesar $0,0007 \mathrm{~m}^{3} / \mathrm{s}$ dengan menggunakan 6 panel surya untuk sistem irigasi sederhana.

Tabel 9. Debit Air pada Sudut Panel $10^{\circ}$

\begin{tabular}{cccccc}
\hline Hari/Tanggal/Waktu Percobaan & $\mathrm{h}(\mathrm{m})$ & $\mathrm{I}\left(\mathrm{W} / \mathrm{m}^{2}\right)$ & $\mathrm{t}(\mathrm{s})$ & $\mathrm{V}\left(\mathrm{m}^{3}\right)$ & $\mathrm{Q}\left(\mathrm{m}^{3} / \mathrm{s}\right)$ \\
\hline Senin, 3 September 2018 pukul 15.00 WIB & 1 & $2.942,84$ & 247,2 & 0,08708 & 0,000352 \\
Rabu, 5 September 2018 pukul 15.00 WIB & 1,5 & $1.697,13$ & 63 & 0,02431 & 0,000386 \\
Kamis, 6 September 2018 pukul 15.00 WIB & 0,5 & $2.485,72$ & 198 & 0,07569 & 0,000382 \\
\hline
\end{tabular}

Tabel 10. Debit Air pada Sudut Panel $10^{\circ}$

\begin{tabular}{lccccc}
\hline Hari/Tanggal/Waktu Percobaan & $\mathrm{h}(\mathrm{m})$ & $\mathrm{I}\left(\mathrm{W} / \mathrm{m}^{2}\right)$ & $\mathrm{t}(\mathrm{s})$ & $\mathrm{V}\left(\mathrm{m}^{3}\right)$ & $\mathrm{Q}\left(\mathrm{m}^{3} / \mathrm{s}\right)$ \\
\hline Jumat, 7 September 2018 pukul 15.00 WIB & 1,5 & $3.062,84$ & 367,2 & 0,1413 & 0,000385 \\
Sabtu, 8 September 2018 pukul 15.00 WIB & 1 & $2.337,13$ & 124,2 & 0,05363 & 0,000432 \\
Minggu, 9 September 2018 pukul 15.00 WIB & 0,5 & $1.759,7$ & 53 & 0,01217 & 0,000230 \\
\hline
\end{tabular}

\section{KESIMPULAN DAN SARAN}

Berdasarkan hasil penelitian yang telah dilakukan, dapat disimpulkan bahwa terdapat pengaruh perbedaan kedalaman pipa terhadap daya listrik pompa air tenaga surya yang dihasilkan, yakni semakin besar kedalaman pipa maka daya listrik pompa juga semakin besar. Daya listrik tertinggi pada pompa air terdapat pada kedalamam pipa 1,5 meter sebesar 176 Watt dan daya listrik pompa air terendah terdapat pada kedalaman 0,5 meter sebesar 132 Watt. Debit air tertinggi terdapat pada hari Sabtu, 8 September 2018 sebesar $0,000432 \mathrm{~m}^{3} / \mathrm{s}$ dan debit air terendah terdapat pada hari Minggu, 9 September 2018 yakni sebesar $0,000230 \mathrm{~m}^{3} / \mathrm{s}$. Efisiensi pompa air tertinggi terdapat pada hari Jumat, 7 September 2018 sebesar 10,88\% dengan lama waktu pompa air beroperasi selama 367,2 detik. dan efisiensi pompa air terendah terdapat pada hari Minggu, 9 September 2018 sebesar 2,958\% dengan lama waktu pompa air beroperasi sebesar 53 detik. Efisiensi pompa air terhadap matahari tertinggi terdapat pada hari Jumat, 7 September 2018 sebesar $0,900 \%$ dan nilai efisiensi pompa air terhadap matahari terendah terdapat pada hari Minggu, 9 September 2018 sebesar 0,170\%. Efisiensi pompa air terhadap panel surya tertinggi terdapat pada hari Jumat, 7 September 2018 sebesar 8,120\% dan nilai efisiensi pompa air terhadap matahari terendah terdapat pada hari Minggu, 9 September 2018 sebesar 2,604\%. Perlu penelitian lanjutan dengan mengaplikasikan sistem irigasi pompa air tenaga surya pada tanaman tertentu, untuk memaksimalkan kinerja pompa air digunakan pompa air berjenis motor arus searah. 


\section{DAFTAR PUSTAKA}

Apribowo, C.H.B, T.E. Saraswati dan M. Anwar. 2017. Prototype Sistem Pompa Air Tenaga Surya Untuk Meningkatkan Produktivitas Hasil Pertanian. Jurnal Abdimas. Vol. 21, No.2: 97-101

Ariawan, A.T, T.I. Partha dan I.W.A. Wijaya. 2013. Perbandingan Penggunaan Motor DC dengan AC Sebagai Penggerak Pompa Air yang Disuplai Oleh Sistem Pembangkit Listrk Tenaga Surya (PLTS). Proceeding Conference on Smart-Green Technology in Electrical and Information System, Bali.

Green, J, A. Gandhi, E. Ilten, B. Lake, V. Pandya, S.L. Pesek, J.B. Spielberg dan C. Sung. 2017. Solar Water Pumps: Technical, Systems And Business Model Approaches To Evaluation. Massachusetts Institute of Technology, Cambridge.

Saputra, F. Kinerja Pompa Air DC Berdasarkan Intensitas Tenaga Surya. Tugas Akhir. Fakultas Teknik, Universitas Muhammadiyah Surakarta, Surakarta.

Setiadi dan I. M. A. Djoni. 2013. Perancangan Pompa Torak 3 Silinder Untuk Injeksi Lumpur Kedalaman 10000 FT dengan Debit 500 GPM (Studi Kasus Sumur Pemboran Pertamina Hulu Energi-West Madura Offshore). Jurnal Sains dan Seni Pomits. Vol. 2, No. 2: 197-201.

Setiadi, R.L, E. Suryadi dan S. Dwiratna. 2017. Kajian Pemanfaatan Pompa Air Tenaga Surya Untuk Kebutuhn Irigasi di Lahan Pertanian. Prosiding Seminar Nasional Lahan Suboptimal 2017, Palembang.

Wardjito. 2012. Perencanaan Instalasi Pompa Return Pump dengan Kapasitas $130 \mathrm{M}^{3} / \mathrm{Jam}$ Untuk Exchanger Heater Pompa. Jurnal Keilmuan dan Terapan Teknik. Vol. 1, No. 1: $53-64$

Yasar, M, Mustaqimah, Y. Yunus, Mahfuddin dan Asrillah. 2017. Prediksi Potensi Air Tanah untuk Optimasi Sawah Tada Hujan Dalam Menunjang Ketahanan Pangan. Jurnal Lahan Suboptimal. Vol. 6, No. 2: 170-175. 